\title{
International practice in relation to hastened death and assisted dying
}

This themed series of Annals of Palliative Medicine is focused on the broad topic of hastened death. In palliative care, a hastened death is when a person who has a life limiting illness has the wish, desire, or intentionally seeks to end their life prematurely $(1,2)$. We are proposing that hastened death includes, but is not exclusive of, lawful assisted dying where an individual who meets a specific criterion can be prescribed or administered medications to end their life. It may also include when a person with a life limiting illness has a deliberate planned effort to die sooner than anticipated by voluntarily stopping eating and drinking. Where we use the phrase assisted dying, it generally refers to legalized forms of hastened death which may include health care professionals. We prepared this themed series of Annals of Palliative Medicine to give an overview of different forms of hastened death and assisted dying internationally, how palliative care services work with legislation, and present options that some individuals who desire a hastened death consider when coping with life limiting illnesses. What this series does not include are articles about individuals who deliberately end their life by suicide without medical assistance or care.

Hastened death is a contentious issue, not least for those working in palliative care. Palliative care organizations have traditionally been in opposition, although there have been notable exceptions (3-5). Palliative care professionals may view assisted dying and palliative care as distinct from each other or integrated into end-of-life practices (6-8). However, there can be a great deal of misunderstandings about assisted dying on all sides of the argument.

We began preparing this series prior to the outbreak of the COVID-19 global pandemic. We invited authors to submit articles about different parts of the world that currently have lawful assisted dying, are actively engaged in trying to pass laws, or do not have laws. We sought articles from palliative care practitioner, patient, or public perspectives. The pandemic is a crisis that palliative care teams have not seen before, and in this themed series we only have anecdotal evidence written by physicians in Canada (9), that requests for assisted dying are increasing as a result. This increase in requests for assisted dying is perhaps due to fear that patients will not be able to receive optimum palliative care as healthcare resources come under pressure or that the processes involved in gaining an assisted death might be impaired.

There appears to be momentum internationally to permit some form of assisted dying within legal processes, with the Governments in areas of Australia, Germany, Ireland, Portugal, Spain, and New Zealand being the latest to produce legislation in support of these practices (10-12). Whilst there are many similarities in permissive legislation internationally, there are also many differences, not least in the terminology used and what that terminology represents. Assisted dying, physician-assisted suicide, medical aid in dying, euthanasia and hastened death are just some of the terms used. Euthanasia, a term commonly used in Europe (13), is a medical act to deliberately assist to end someone's life to relieve suffering. It is also known as medical assistance in dying (e.g., Canada) that primarily refers to when a medical practitioner, a physician and in some areas, a nurse practitioner $(10,14,15)$, administers a drug to a requesting patient to cause their death. The selfadministered assistance in dying in some areas of the world is called assisted suicide (e.g., Switzerland), and in others is called Death with Dignity (e.g., Oregon, Washington state) or medical aid in dying. The self-administered type of assistance in dying is when a medical practitioner prescribes a medication that the patient ingests without assistance and the medical practitioner is not necessarily required to be present at the time of death. Euthanasia and physician assisted suicide are terms primarily used in European countries that have these practices. However, the terms medical aid in dying, medical assistance in dying, and voluntary assisted dying are increasingly used in North America and Australia. The use of different terminology and a detailed overview is discussed in the paper by Mroz et al. (13) (in 2020). As this special series goes to press New Zealand has passed the End of Life Choice Act (15), and Western Australia has passed the Voluntary Assisted Dying Act (10) adding to the language, and variations of assisted dying around the world.

Of note, the impact of the COVID-19 pandemic has caused an increased dependence on utilizing healthcare technologies to prevent the spread of the virus and it appears that some provider organizations are actively addressing this as an issue in assisted dying. In Canada, for example, the Canadian Association of MAiD Assessors and Providers (CAMAP) have developed guidance to assure safety for providers, patients, and families that include encouraging use of telemedicine when possible, oral medications over IV medications to minimize exposure, and limiting how many can be present at the death (16). Even in the 
UK where it is an offense to encourage or assist the death of another person, people are permitted to travel abroad during lockdown to jurisdictions where assisted dying is allowed (17).

To give an international perspective, the articles included in this themed series originates from authors located in Belgium, Germany, Netherlands, New Zealand, North America, and the United Kingdom. Firstly, Mroz et al. (13) present an overview of assisted dying around the world and place the development in terms of current legislation. Gerson et al. (18) completed a qualitative interview study about the relationship of palliative care with assisted dying in Flanders, Quebec, and Oregon, each with different types of assisted dying. The authors explore how and if palliative care practitioners have integrated assisted dying as an element of their care with patients seeking to hasten death. They found that there is no uniform relationship between assisted dying and palliative care, but that the relationship is influenced by changing legal regulations, varying or inconsistent institutional policies, and individual perspectives of the involved palliative care professionals.

Analysis of a survey on hastened death in the Netherlands is presented by Overbeek et al. (19) This further develops the discussion about the use of various terminology in this area. It demonstrates how hastened deaths are recorded varies and terminology related to hastened death is used less often if the patient is in the last 1-7 days of life. Here acts are more commonly classified as palliative or terminal sedation. Indeed, there is concern about what is a considered a hastened death (1). These discrepancies are further explored by Young et al. (20) who interviewed patients with a life limiting condition in relation to what constitutes a hastened death in New Zealand. The paper, written prior to passing the End of Life Choice Act in New Zealand, gives an interesting perspective and highlights that what clinicians and ethicists might view as hastened death may not be shared by patients.

Australia introduced assisted dying legislation in the state of Victoria in 2017, and Hempton gives an overview of the policies and legalities involved. It is interesting to compare this to the paper by Wiebe et al. (9) who explore current practice in Canada and give some personal accounts for clinicians. In all of these papers the role of palliative care is present but the paper by Kremeike et al. (21) takes us through the development of the German guidelines to address the desire to die in Germany. Whilst completing the article, there was new legislation related to assisted dying, which they incorporate into the paper.

Finally, the paper by Lowers et al. (22), about voluntary stopping eating and drinking (VSED), demonstrates that forms of assisted dying occur outside of assisted dying laws and regulations. VSED is a form of hastened death, as an intentional act, but may not be limited to those at the end of life.

What this series does not cover is an in-depth analysis or exploration of palliative sedation, which some, but not all, may consider a hastened death (23). In addition, this series does not cover how individuals receiving palliative care may hasten death by suicide (24).

As legislation for different forms of assisted dying are increasingly passed around the world, palliative care practitioners need to evaluate the at times difficult relationship they have with the legal desire of patients to ask for a hastened death. For some this will challenge their own views and practice. By bringing together key research in this area, we hope practitioners will be better equipped to consider the issues hastened death brings, decide upon their own role, and find ways to address caring for, listening to and being with their patients.

\section{Acknowledgments}

Funding: None.

\section{Footnote}

Provenance and Peer Review: This article was commissioned by the editorial office, Annals of Palliative Medicine. The article did not undergo external peer review.

Conflicts of Interest: Both authors have completed the ICMJE uniform disclosure form (available at http://dx.doi.org/10.21037/ apm-21-300). NP serves as an unpaid editorial board member of Annals of Palliative Medicine from May 2019 to Apr 2021. Both authors served as the unpaid Guest Editors of the series and have no other conflicts of interest to declare.

Ethical Statement: The authors are accountable for all aspects of the work in ensuring that questions related to the accuracy or 
integrity of any part of the work are appropriately investigated and resolved.

Open Access Statement: This is an Open Access article distributed in accordance with the Creative Commons AttributionNonCommercial-NoDerivs 4.0 International License (CC BY-NC-ND 4.0), which permits the non-commercial replication and distribution of the article with the strict proviso that no changes or edits are made and the original work is properly cited (including links to both the formal publication through the relevant DOI and the license). See: https://creativecommons.org/licenses/by-nc$\mathrm{nd} / 4.0 /$.

\section{References}

1. Gerson SM, Bingley A, Preston N, et al. When is hastened death considered suicide? A systematically conducted literature review about palliative care professionals' experiences where assisted dying is legal. BMC Palliat Care 2019;18:75.

2. Rodríguez-Prat A, Balaguer A, Booth A, et al. Understanding patients' experiences of the wish to hasten death: an updated and expanded systematic review and meta-ethnography. BMJ Open 2017;7:e016659.

3. Bernheim JL, Distelmans W, Mullie A, et al. Questions and answers on the Belgian model of integral end-of-life care:

Experiment? Prototype?: 'Eu-euthanasia': The close historical, and evidently synergistic, relationship between palliative care and euthanasia in Belgium: An interview with a doctor involved in the early development of both and two of his successors. J Bioeth Inq 2014;11:507-29.

4. Inbadas H, Carrasco JM, Clark D. Representations of palliative care, euthanasia and assisted dying within advocacy declarations. Mortality (Abingdon) 2019;25:138-50.

5. Inbadas H, Zaman S, Whitelaw S, et al. Declarations on euthanasia and assisted dying. Death Stud 2017;41:574-84.

6. Bernheim JL, Deschepper R, Distelmans W, et al. Development of palliative care and legalisation of euthanasia: antagonism or synergy? BMJ 2008;336:864-7.

7. Buchman S. Why I decided to provide assisted dying: it is truly patient centred care. BMJ 2019;364:1412.

8. Emanuel EJ, Onwuteaka-Philipsen BD, Urwin JW, et al. Attitudes and Practices of Euthanasia and Physician-Assisted Suicide in the United States, Canada, and Europe. JAMA 2016;316:79-90.

9. Wiebe E, Green S, Wiebe K. Medical assistance in dying (MAiD) in Canada: practical aspects for healthcare teams. Ann Palliat Med 2021;10:3586-93.

10. Western Australia. Voluntary Assisted Dying Act 2019. Available online: https://www.legislation.wa.gov.au/legislation/prod/ filestore.nsf/FileURL/mrdoc_42491.pdf/\$FILE/Voluntary\%20Assisted\%20Dying\%20Act\%202019\%20-\%20\%5B00-0000\%5D.pdf?OpenElement

11. Shannon J. Physician-assisted dying: Complex issue that requires open and honest debate. The Irish Times, Nov 10, 2020.

12. AP. Spain's parliament votes to legalize euthanasia 2020. Available online: https://apnews.com/article/portugal-madrid-assistedsuicide-euthanasia-bills-dd1929fd0faae9da1b5a4c294b4fb2b5

13. Mroz S, Dierickx S, Deliens L, et al. Assisted dying around the world: a status quaestionis. Ann Palliat Med 2021;10:3540-53.

14. Government of Canada. Legislative Background: Medical Assistance in Dying. In: Justice Do, (ed.). Government of Canada, 2016. Available online: http://www.justice.gc.ca/eng/rp-pr/other-autre/adra-amsr/adra-amsr.pdf

15. Ministry of Health. New Zealand End of Life Choice Act 2019. Available online: https://www.health.govt.nz/our-work/ regulation-health-and-disability-system/end-life-choice-act

16. Canadian Association of MAiD Assessors and Providers. Guidance for assessors and providers of Medical Assistance in Dying (MAiD) during the COVID-19 pandemic. Available online: https://camapcanada.ca/wp-content/uploads/2020/04/FormattedFinal-MAiD-in-Covid.pdf

17. BBC News. Covid-19: Assisted dying travel allowed during lockdown, says Hancock. Available online: https://www.bbc.com/ news/uk-politics-54823490

18. Gerson SM, Koksvik GH, Richards N, et al. Assisted dying and palliative care in three jurisdictions: Flanders, Oregon, and Quebec. Ann Palliat Med 2021;10:3528-39.

19. Overbeek A, van de Wetering VE, van Delden JJ, et al. Classification of end-of-life decisions by Dutch physicians: findings from a cross-sectional survey. Ann Palliat Med 2021;10:3554-62. 
20. Young JE, Winters J, Jaye C, et al. Patients' views on end-of-life practices that hasten death: a qualitative study exploring ethical distinctions. Ann Palliat Med 2021;10:3563-74.

21. Kremeike K, Pralong A, Boström K, et al. 'Desire to Die' in palliative care patients_legal framework and recommendations of the national evidence-based guideline on palliative care in Germany. Ann Palliat Med 2021;10:3594-610.

22. Lowers J, Hughes S and Preston NJ. Overview of voluntarily stopping eating and drinking to hasten death. Ann Palliat Med 2021;10:3611-6.

23. Heijltjes MT, van Thiel GJMW, Rietjens JAC, et al. Changing Practices in the Use of Continuous Sedation at the End of Life: A Systematic Review of the Literature. J Pain Symptom Manage 2020;60:828-46.e3.

24. Gerson SM, Preston N and Bingley A. Medical Aid in Dying, Hastened Death and Suicide: A Qualitative Study of Hospice Professionals' Experiences from Washington State. J Pain Symptom Manage 2020;59:679-86.e1.

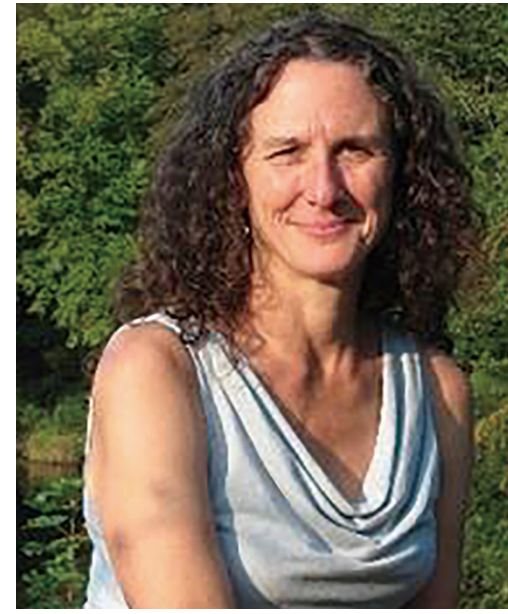

Sheri Mila Gerson

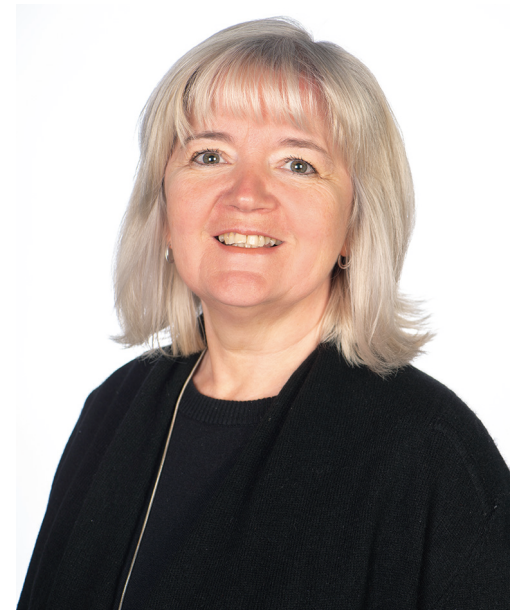

Nancy Preston

Sheri Mila Gerson

Compassionate Care Counseling and Consulting, PLLC, Olympia, Washington, USA. (Email: sherimila@gmail.com)

Nancy Preston

Professor of Supportive and Palliative Care, International Observatory on End of Life Care, Lancaster University, Lancaster, UK.

(Email: n.j.preston@lancaster.ac.uk)

Submitted Feb 01, 2020. Accepted for publication Feb 09, 2021.

doi: 10.21037/apm-21-300

View this article at: http://dx.doi.org/10.21037/apm-21-300

Cite this article as: Gerson SM, Preston N. International practice in relation to hastened death and assisted dying. Ann Palliat Med 2021;10(3):3524-3527. doi: 10.21037/apm-21-300 